Research Paper

\title{
Efiects of Female Sex Hormones on Clusterin Expression and Paclitaxel Re- sistance in Endometrial Cancer Cell Lines
}

\author{
Yong Sung Won ${ }^{1}$, Sung Jong Lee ${ }^{3}$, Seung Geun Yeo², Dong Choon Park ${ }^{3 凶}$ \\ 1. Department of Surgery St. Vincent's Hospital, The Catholic University of Korea. \\ 2. East-West Medical Research Institute, Kyung Hee University. \\ 3. Department of Obstetrics and Gynecology, St. Vincent's Hospital, The Catholic University of Korea.
}

$\checkmark$ Corresponding author: Dong Choon Park, M.D., PhD. Department of Obstetrics and Gynecology, Saint Vincent's Hospital, The Catholic University of Korea, 93 Gi-dong, Paldal-ku, Suwon, Kyungki-do, Korea. Phone: 82-31-249-8221; Fax: 82-31-254-7481; E-mail:dcpark@catholic.ac.kr

(C) Ivyspring International Publisher. This is an open-access article distributed under the terms of the Creative Commons License (http://creativecommons.org/ licenses/by-nc-nd/3.0/). Reproduction is permitted for personal, noncommercial use, provided that the article is in whole, unmodified, and properly cited.

Received: 2011.10.20; Accepted: 2011.12.05; Published: 2011.12.11

\begin{abstract}
Objective: We have analyzed the association between clusterin expression in endometrial cancer cells and their resistance to paclitaxel. We also analyzed whether the effects of female sex hormones on clusterin expression by these cell lines affect their resistance to paclitaxel. Methods: The expression of estrogen receptors $\alpha$ and $\beta$, progesterone receptors $A B$ and $B$, and clusterin mRNA and protein was assayed in the ECC-I and KLE endometrial cancer cell lines by RT-PCR and Western blotting, respectively. The $\mathrm{IC}_{50}$ of paclitaxel was measured in each cell line by XTT assay. Using clusterin siRNA, we analyzed the association between clusterin expression and paclitaxel $I_{50}$ in each cell line. We also examined the effects of hormone treatment on cellular resistance to paclitaxel. Results: Paclitaxel IC $\mathrm{C}_{50}$ was significantly higher in KLE cells, which expressed higher levels of clusterin, than in ECC-I cells, which expressed lower levels of clusterin. Conversely, incubation with clusterin siRNA significantly decreased the viability of KLE cells $(P<0.00 \mathrm{I})$, but did not alter the viability of ECC-I cells. Incubation with estrogen tended to increase the level of clusterin expression in these endometrial cancer cell lines, although the level of clusterin expression did not correlate with that of estrogen receptors. Incubation with progesterone did not alter the levels of expression of clusterin and clusterin receptor. Incubation with estrogen and paclitaxel significantly increased the viability of ECC-I $(P<0.00 I)$ but not KLE cells. Conclusion: Estrogen increases the paclitaxel resistance of endometrial cancer cell lines, by increasing clusterin expression.
\end{abstract}

Key words: endometrial cancer, Clusterin, Paclitaxel, Estrogen, Progesterone.

\section{Introduction}

Endometrial cancer is representative of hormone dependent gynecologic cancers [1]. However, attempts to treat female hormone dependent cancers with anti-hormonal treatments have not been effective, except in early stage cancers. Although the leading cause of treatment failure was drug resistance, the mechanisms by which these tumors become resistant to chemotherapeutic agents have not been clarified. Tumors in patients resistant to an- ti-cancer drugs were recently reported to show increased expression of clusterin, which acts as a cytoprotective protein of cancer cells [2].

The gene encoding clusterin is located on chromosome 8p21-p12 [3]. Clusterin is a 75-80 kDa disulfide-linked heterodimeric protein that exists as several subtypes due to alternative splicing [4-7]. Clusterin is also known as TRPM-2 (testosterone repressed prostate message- 2), SGP-2 (sulfated glycoprotien-2), and 
Sp-40 and Apo-J (apoliprotein J) [4-7]. When the entire gene is expressed, each clusterin molecule is expressed as an approximately $60 \mathrm{kDa}$ precursor, which, after glycosylation, is converted to an approximately $80 \mathrm{kDa}$ secretory protein [8]. When exon 2 is spliced out during transcription, however, the protein synthesized is approximately $55 \mathrm{kDa}$ in size. Although the function of clusterin has not been determined, it is reported to act as a protective protein [9]. Clusterin is expressed in various cells and tissues and has been shown to function in cell adhesion and aggregation, complement inhibition, lipid transport, membrane protection and endocrine secretion $[10,11]$. Clusterin overexpression has been reported in bladder, cervical, breast and prostate cancers [12-15]. For example, in an animal model of androgen independent prostate cancer, simultaneous treatment with paclitaxel and clusterin antisense-oligonucleotide enhanced the drug response rate [16]. Moreover, suppression of clusterin gene expression in prostate cancer cells was found to inhibit their proliferation and to enhance response to anticancer drugs [17]. However, there have been few studies on the effects of female hormones on clusterin expression in hormone dependent tumors. We therefore evaluated the correlation between clusterin expression and paclitaxel resistance in hormone dependent endometrial cancer cell lines, as well as the effects of female hormones on clusterin expression.

\section{Material and methods}

\section{Cell lines and culture conditions}

The endometrial cancer cell lines, KLE and ECC-1, were purchased from the American Type Culture Collection (ATCC, Atlanta, GA, USA) and were cultured in RPMI1640 medium (Gibco, Grand Island, $\mathrm{NY}, \mathrm{USA}$ ) in a $5 \% \mathrm{CO}_{2}$ environment.

\section{Investigation of gene expression}

\section{I) RNA isolation and cDNA synthesis}

Total RNA was isolated from cultured cell lines using TRIzol reagent (Invitrogen, Carlsbad, CA, USA). The cells were dissolved in TRIzol and centrifuged after adding bromochloropropane (Sigma, St. Louis, MO, USA). RNAs were precipitated with isopropanol, washed with ethanol to remove impurities, and dissolved in DEPC (diethyl pyrocarbonate)-treated distilled water. RNA concentrations were quantified spectrophotometrically (Thermo Fisher Scientific, IL, USA). To synthesize cDNA, RNA was incubated for 5 minutes at $70^{\circ} \mathrm{C}$; Reverse Transcription Master premix (Elpis, Taejeon, Korea) was added; and cDNA was synthesized by reverse tran- scription for 60 minutes at $42^{\circ} \mathrm{C}$, followed by inactivation of the enzyme for 5 minutes at $94^{\circ} \mathrm{C}$.

\section{2) Reverse transcription Polymerase chain reaction, RT-PCR}

Using PCR premixture (Promega, Madison, WI, USA), cDNA sequences encoding estrogen receptors a and $\beta$, progesterone receptors $\mathrm{AB}$ and $\mathrm{B}$, and clusterin were amplified by PCR; a $\beta$-actin cDNA sequence was amplified as a loading control (Table 1). The PCR products were electrophoresed in 1-2\% agarose gels, and the amount in each band was quantitatively analyzed using the Quantity One program (Bio Rad, Hercules, CA, USA). Each band was normalized relative to the $\beta$-actin band in the same sample.

Table I. Sequence of primers and PCR conditions.

\begin{tabular}{|c|c|c|c|c|}
\hline Primer & & Sequence $\left(5^{\prime} \rightarrow 3^{\prime}\right)$ & $\begin{array}{l}\text { Product } \\
\text { Size } \\
\text { (bp) }\end{array}$ & $\begin{array}{l}\text { Annealing } \\
\text { Temperature } \\
\left({ }^{\circ} \mathrm{C}\right)\end{array}$ \\
\hline \multirow[t]{2}{*}{ Clusterin } & $\mathrm{F}$ & $\begin{array}{l}\text { TTC CCA CAC TTC TGA } \\
\text { CTC GGA C }\end{array}$ & 193 & 58 \\
\hline & $\mathrm{R}$ & $\begin{array}{l}\text { AAC ATC CAC ATC TCA } \\
\text { CTC CTC C }\end{array}$ & & \\
\hline \multirow[t]{2}{*}{ ER a } & $\mathrm{F}$ & $\begin{array}{l}\text { ATA CGA AAA GAC } \\
\text { CGA AGA GGA G }\end{array}$ & 417 & 55 \\
\hline & $\mathrm{R}$ & $\begin{array}{l}\text { CCA GAC GAG ACC AAT } \\
\text { CAT CA }\end{array}$ & & \\
\hline \multirow[t]{2}{*}{ ER $\beta$} & $\mathrm{F}$ & $\begin{array}{l}\text { GGA TGA GGG GAA } \\
\text { ATG CGT AGA A }\end{array}$ & 435 & 59 \\
\hline & $\mathrm{R}$ & $\begin{array}{l}\text { CCC GTG ATG GAG GAC } \\
\text { TTG C }\end{array}$ & & \\
\hline \multirow[t]{2}{*}{$\mathrm{PR} A B$} & $\mathrm{~F}$ & $\begin{array}{l}\text { AGC CGG TCC GGG TGC } \\
\text { AAG }\end{array}$ & 242 & 62 \\
\hline & $\mathrm{R}$ & $\begin{array}{l}\text { CCA CCC AGA GCC CGA } \\
\text { GG }\end{array}$ & & \\
\hline \multirow[t]{2}{*}{ PR B } & $\mathrm{F}$ & $\begin{array}{l}\text { ACT GAG CTG AAG GCA } \\
\text { AAG GGT }\end{array}$ & 201 & 64 \\
\hline & $\mathrm{R}$ & $\begin{array}{l}\text { GTC CTG TCC CTG GCA } \\
\text { GGG C }\end{array}$ & & \\
\hline \multirow[t]{2}{*}{$\beta$ actin } & $\mathrm{F}$ & $\begin{array}{l}\text { GTG GGG CGC CCC AGG } \\
\text { CAC CAG GGC }\end{array}$ & 540 & 58 \\
\hline & $\mathrm{R}$ & $\begin{array}{l}\text { CTC CTT AAT GTC ACG } \\
\text { CAC GAT TTC }\end{array}$ & & \\
\hline
\end{tabular}

\section{3) Western blotting}

Proteins were extracted from cells using a lysate buffer (Intron Biotechnology, Gyeonggi-Do, Korea) and quantified by the Bradford assay. Aliquots containing of $20 \mu \mathrm{g}$ protein were electrophoresed on $10 \%$ SDS-PAGE gels for 2 hours at $80 \mathrm{~V}$. Proteins were transferred to PVDF membranes (Bio Rad) for 1 hour at $15 \mathrm{~V}$ using a Semi-Dry transfer unit (Bio Rad). Following preincubation with a blocking agent, the membranes were incubated with a monoclonal antibody to clusterin (Millipore, Temecula, CA, USA), followed by incubation with species specific second- 
ary antibody. As a loading control, the membranes were incubated with a monoclonal antibody to $\beta$-actin (Cell Signaling, Danver, MA USA). Protein expression was developed using ECL (Enhanced chemiluminescence; Thermo Fisher Scientific) and analyzed with the Quantity One program (Bio Rad.)

\section{Paclitaxel IC 50 (50\% inhibitory concentra- tion)}

Cells were placed in 96-well plates $\left(1 \times 10^{4}\right.$ cells per well) and incubated for 48 hours with various concentrations $\left(10^{-4} \mathrm{M} \sim 10^{-12} \mathrm{M}\right.$ ) of paclitaxel (Hanmi, Gyeoggi-Do, Korea). Cell proliferation was determined using XTT assays (cell proliferation kit; Roche, Mannheim, Germany), and the paclitaxel IC50 of each cell line was determined.

\section{Inhibition of clusterin expression using RNA interference}

Clusterin siRNA duplex, consisting of nucleotides +85 to +96 (where the translation start site was defined as +1; (Dharmacon Research, Lafayette, CO), or luciferase GL2 Duplex (Dharmacon) at 0.2 $\mathrm{nmol} / \mathrm{ml}$ was transfected into endometrial cancer cells using oligofectamine reagent (Invitrogen, Carlsbad, CA), as described by the manufacturer's protocols (Life Technologies, Inc., Gaithersburg, MD). Transfected cells were evaluated for clusterin expression and sensitivity to paclitaxel.

\section{Treatment with female hormones}

Cells were incubated with estrogen ( $\beta$ estradiol; Sigma), at concentrations of $0,2,20,200$, and $2000 \mathrm{nM}$, and progesterone (Sigma), at concentrations of $0,2,10$, 20 , and $100 \mu \mathrm{M}$, for 24 hours, after which clusterin expression and drug resistance were analyzed.

\section{Treatment with female hormones and paclitaxel}

Cells were incubated with estrogen or progesterone, as above, for 24 hours. Paclitaxel was added and the cells were cultured for an additional 48 hours. XTT assays were performed, and cell survival rates were calculated.

\section{Statistical analysis.}

Groups were compared using Student's t-tests. A $P$ value less than 0.001 was defined as statistically significant.

\section{Results}

\section{Hormone receptor and clusterin expression in endometrial cancer lines}

The expression in each cell line of hormone receptor and clusterin mRNA was evaluated using RT-PCR. Only ER $\beta$ was expressed in KLE cells, whereas the ER $\alpha$, ER $\beta$, PR AB, and PR B were all expressed in ECC-1 cells (Figure 1). The levels of clusterin mRNA expression were three-fold higher in KLE than in ECC-1 cells (Figure 2).

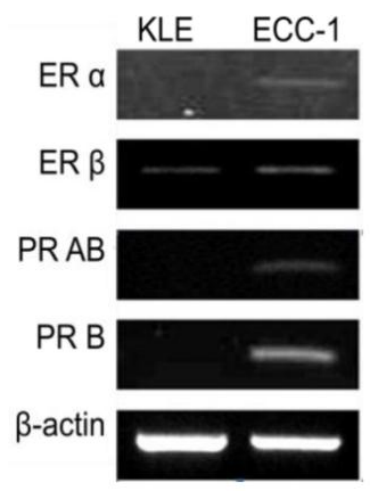

Figure I. RT-PCR of ER (Estrogen receptor) $\alpha, \beta, P R$ (Progesterone receptor) AB, $B$ and $\beta$-actin in endometrial cancer cell lines (KLE, ECC-I).

a.

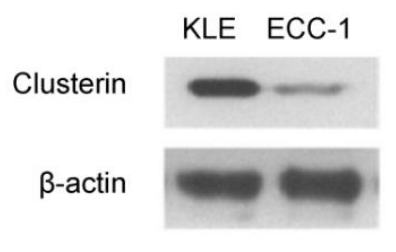

b.

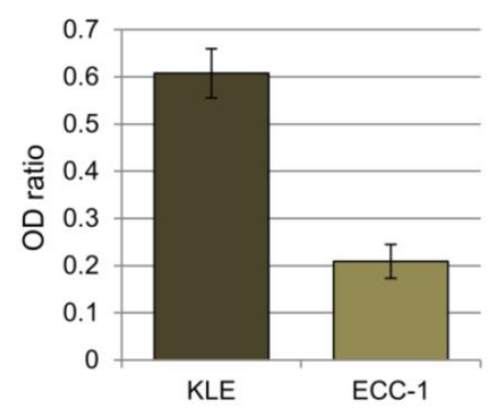

Figure 2. a. Western blotting of clusterin and $\beta$-actin in endometrial cancer cell line (KLE, ECC-I). b. The graph shows the ratio between the clusterin and $\beta$-actin band density. 


\section{Clusterin expression and resistance to paclitaxel.}

Cellular resistance to paclitaxel was analyzed using XTT assays. We found that the paclitaxel $\mathrm{IC}_{50}$ was 50-fold higher in KLE cells $\left(5 \times 10^{-5} \mathrm{M}\right)$, which showed a high level of clusterin mRNA expression, than in ECC-1 cells $\left(10^{-6} \mathrm{M}\right)$, which showed a low level of clusterin expression.

\section{Inhibition of clusterin expression using siRNA and resistance to paclitaxel}

To determine whether clusterin expression was associated with sensitivity to paclitaxel, we transfected cells with clusterin siRNA and analyzed cell survival rate after treatment with paclitaxel. Suppression of clusterin expression in KLE cells was associated with a significant decrease in cell survival rate $(\mathrm{P}$ $<0.001$ ), whereas clusterin siRNA had no effect on the survival rate of ECC-1 cells (Figure 3).

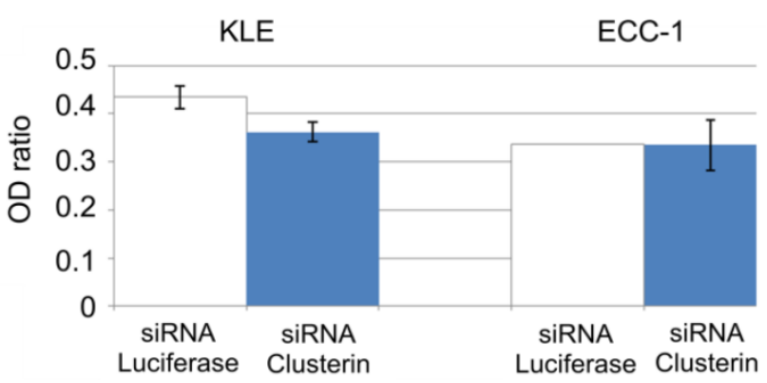

Figure 3. Cell survival ratio by XTT. Clusterin expression is inversely correlated with cytotoxic effects of paclitaxel. (*; $P<0.00 I)$ White bars are treated siRNA luciferase as transfection control gene. Blue bars are treated siRNA clusterin.

a. KLE

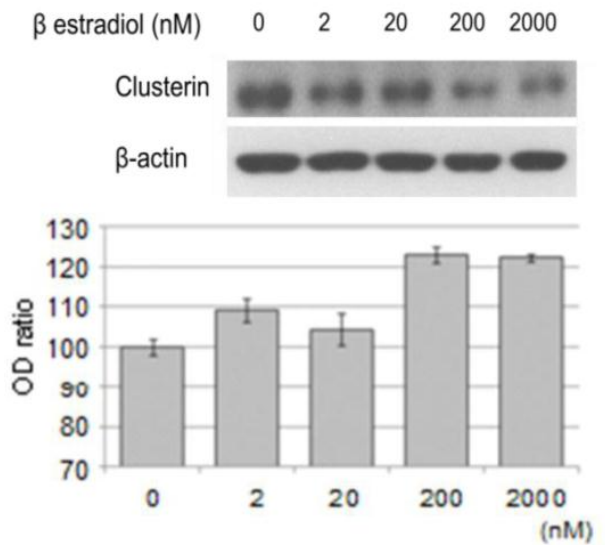

\section{Changes in clusterin expression during treatment with female hormones}

\section{I) Estrogen treatment}

When KLE cells, which express the ER $\beta$ receptor, were treated with $200 \mathrm{nM}$ and $2000 \mathrm{nM}$ estrogen for 24 hours, the expression of clusterin protein increased $23.0 \%$ and $22.3 \%$, respectively, compared with untreated cells. Treatment of ECC-1 cells, which express the ER $\alpha$ and $\beta$ receptors, with these same concentrations of estrogen increased the expression of clusterin protein by $46.9 \%$ and $133.5 \%$, respectively (Figure 4).

\section{2) Progesterone treatment}

Treatment of KLE cells for 24 hours with 2, 10, and $20 \mu \mathrm{M}$ progesterone increased clusterin protein expression $20.4 \%, 27.8 \%$, and $13.1 \%$, respectively, compared with untreated cells. However, incubation of ECC-1 cells with progesterone decreased the expression of clusterin protein (Figure 5).

\section{Effects of female hormones and paclitaxel on cell survival rates}

To analyze the effects of hormones on cell sensitivity to paclitaxel, each cell line was pretreated with $20 \mathrm{nM} \beta$ estradiol for 24 hours, followed by treatment with paclitaxel for 48 hours, and their survival rates were analyzed. We found that $\beta$ estradiol pre-treatment significantly increased the survival rate of ECC-1 (P <0.001), but not KLE, cells in response to paclitaxel treatment (Figure 6a). In contrast, preincubation with $20 \mu \mathrm{M}$ progesterone for 24 hours did not significantly alter the survival rates of both cell lines to treatment with paclitaxel (Figure 6b).

\section{b. ECC-1}

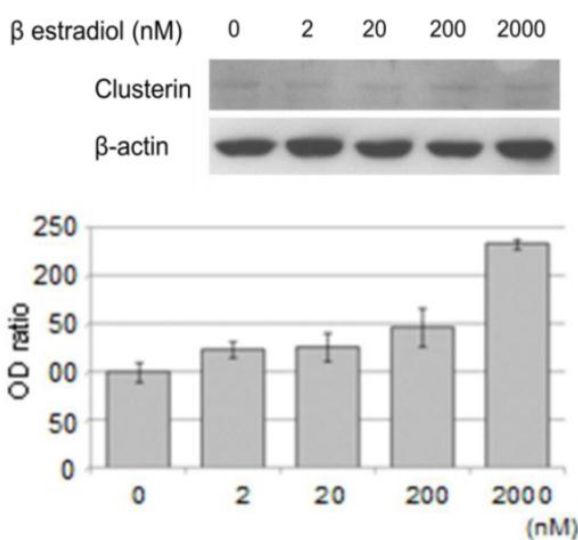

Figure 4. Western blotting of clusterin, $\beta$-actin protein. Each cell line after treatment with the $\beta$ estradiol $(0,2,20,200$, $2000 \mathrm{nM}$ ) were Western blotting. a. KLE, b. ECC-I. The graph shows the ratio between the clusterin and $\beta$-actin band density. 
a. KLE

Progesteron $(\mu \mathrm{M}) \quad 0 \quad 2 \quad 10 \quad 20 \quad 100$

Clusterin

$\beta$-actin
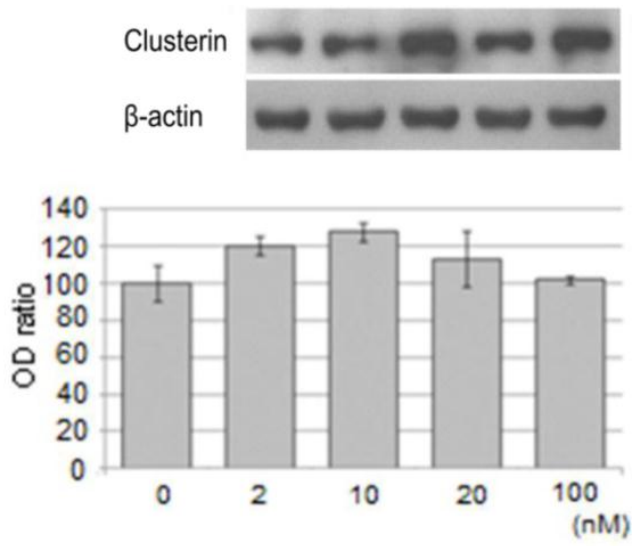

b. ECC-1
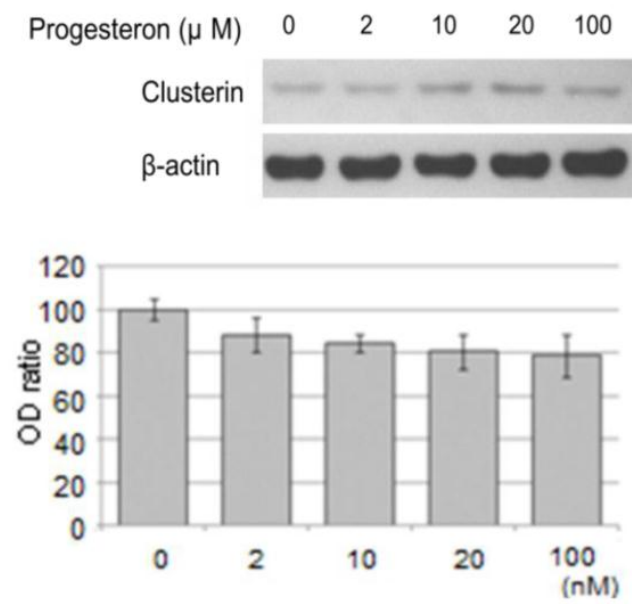

Figure 5. Western blotting of clusterin, $\beta$-actin protein. Each cell line after treatment with the progesterone $(0,2,10,20$, $100 \mu \mathrm{M})$ were western blotting. a. KLE, b. ECC-I. The graph shows the ratio between the clusterin and $\beta$-actin band density.

a. $\beta$ estradiol

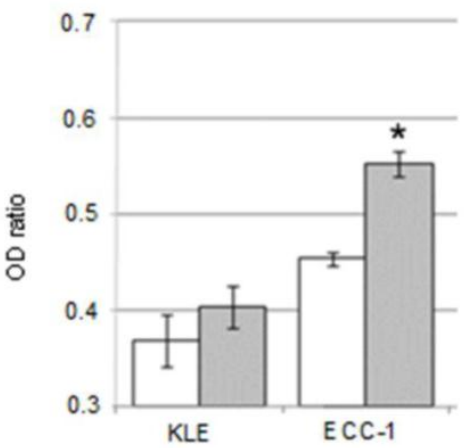

b. Progesterone

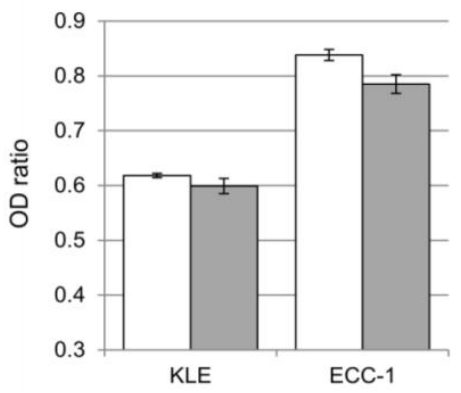

Figure 6. Comparison of cell survival ratio of hormone treatment alone and hormone with paclitaxel treatment. a. $\beta$ estradiol, b. progesterone. (*; $P<0.00 \mathrm{I}$ ) White bars are the hormones that a single treatment. Gray bars are treated with hormone and paclitaxel.

\section{Discussion}

Although clusterin was first isolated in 1983 from the testicular tissues of a lamb [10], its function has not yet been clearly identified [18]. Its presence in various tumors suggests that clusterin inhibits cell-killing during cellular transformation and metastasis [19-23]. In contrast, the expression of clusterin is reduced in some cancers, suggesting that this protein may have pro-apoptotic activity [24]. Its activity as both a pro- and anti-apoptotic protein has suggested that clusterin may be very important in the carcinogenic process. When expressed in secreted form, clusterin functions as an anti-apoptosis agent [25], whereas, expressed in the nucleus, it functions as a pro-apoptosis factor [26]. Overexpression of clusterin during the treatment of patients with prostate, renal, breast and lung cancers has been closely associated with resistance to anti-cancer drugs, including paclitaxel, doxorubicin and cisplatin, and radiation treatments [17, 27-30].

The level of expression of clusterin protein was reported to be higher in the endometrioid than in the papillary type of endometrial cancer, with estrogen found to be associated with the regulation of clusterin protein [31]. Clusterin was shown to have anti-apoptotic activity in breast cancer function [32] and to be associated with growth and metastasis in metastatic breast cancer [33].

To clarify the association between clusterin expression and resistance to paclitaxel in endometrial cancer, we utilized two human endometrial cancer cell lines, KLE and ECC-1, with high and low levels of 
clusterin expression, respectively. We also compared the paclitaxel $\mathrm{IC}_{50}$ and clusterin expression in each cell line, showing that KLE cells had a 10- to 50-fold higher $\mathrm{IC}_{50}$ than ECC-1 cells. After suppressing clusterin expression using a specific siRNA, we observed a close inverse association between clusterin expression and paclitaxel resistance, with clusterin siRNA inducing a significant reduction in KLE cell survival rate after paclitaxel treatment, while having no effect on ECC-1 survival rate. These findings suggested that clusterin expression in endometrial cancer cell lines is associated with paclitaxel resistance. Treatment of endometrial cancer cell lines with estrogen induced significant increases in clusterin protein expressions, especially in ECC-1 cells. Incubation of these cells with $200 \mathrm{nM}$ and $2000 \mathrm{nM}$ estrogen increased the clusterin expression 2.03- and 6.0-fold, respectively. Moreover the survival rate of ECC-1 cells was higher after treatment with paclitaxel plus estrogen than after treatment with paclitaxel alone. In the contrary, KLE did not show the significant difference. These findings suggested that estrogen treatment of these cells is involved in resistance to paclitaxel by inducing the over-expression of clusterin. Furthermore, ECC-1 has the ER a and $\beta$ receptors but KLE has the only ER-a receptor. Although we did not evaluate whether estrogen up-regulated clusterin via ER a only or not, ER a may be more closely related with its mechanism than ER- $\beta$.

Treatment of these endometrial cancer cell lines with progesterone did not induce consistent changes in clusterin expression, and treatment of these cells with progesterone and paclitaxel simultaneously had no effect on survival rates. Although progesterone, which antagonizes estrogen, may have anti-cancer properties [34, 35], and $20 \mathrm{nM}$ progesterone seemed to reduce cell survival rate, we found that progesterone did not significantly reduce the survival rate of these two cell lines. Progesterone, however, is likely associated with factors other than clusterin that may alter survival rates.

In conclusion, we found that clusterin expression by endometrial cancer cell lines was closely associated with their resistance to anti-cancer drugs. Since estrogen is associated with the induction of clusterin expression, estrogen is involved in the mechanism that increases cellular resistance to paclitaxel. Assays of clusterin expression in endometrial cancers may predict their resistance to paclitaxel. In addition, inhibiting clusterin expression in endometrial cancers may hold promise for the development of treatment methods.

\section{Conflict of Interest}

The authors have declared that no conflict of interest exists.

\section{References}

1. Ito $\mathrm{K}$, Utsunomiya $\mathrm{H}$, Yaegashi N, Sasano H. Biological roles of estrogen and progesterone in human endometrial carcinoma--new developments in potential endocrine therapy for endometrial cancer. Endocr J. 2007;54:667-79.

2. Toffanin S, Daidone MG, Miodini P, De Cecco L, Gandellini P, Cappelletti V. Clusterin:a potential target for improving response to antiestrogens. Int J Oncol.2008; 33:791-8.

3. Blaschuk O, Burdzy K, Fritz IB. Purification and characterization of a cell-aggregating factor (clusterin), the major glycoprotein in ram rete testis fluid. J Biol Chem. 1983;258:7714-20.

4. Jenne DE, Tschopp J. Molecular structure and functional characterization of a human complement cytolysis inhibitor found in blood and seminal plasma: identity to sulfated glycoprotein 2, a constituent of rat testis fluid. Proc Natl Acad Sci U S A. 1989;86:7123-7

5. Kirszbaum L, Sharpe JA, Murphy B, d'Apice AJ, Classon B, Hudson P, Walker ID. Molecular cloning and characterization of the novel, human complement-associated protein, SP-40,40 : a link between the complement and reproductive systems. EMBO J. 1989;8:711-8.

6. de Silva HV, Harmony JA, Stuart WD, Gil CM, Robbins J. Apolipoprotein J: structure and tissue distribution. Biochemistry. 1990;29:5380-9.

7. Purrello M, Bettuzzi S, Di Pietro C, Mirabile E, Di Blasi M, Rimini R, Grzeschik KH, Ingletti C, Corti A, Sichel G. The gene for SP-40,40, human homolog of rat sulfated glycoprotein 2, rat clusterin, and rat testosterone-repressed prostate message 2, maps to chromosome 8. Genomics. 1991; 10:151-6.

8. O'Sullivan J, Whyte L, Drake J, Tenniswood M. Alterations in the post-translational modification and intracellular trafficking of clusterin in MCF-7 cells during apoptosis. Cell Death Differ. 2003;10:914-27.

9. Yang CR, Leskov K, Hosley-Eberlein K, Criswell T, Pink JJ, Kinsella TJ, Boothman DA. Nuclear clusterin/XIP8, an $\mathrm{x}$-ray-induced Ku70-binding protein that signals cell death. Proc Natl Acad Sci U S A. 2000;97:5907-12.

10. Fritz IB, Burdzy K, Sétchell B, Blaschuk O. Ram rete testis fluid contains a protein (clusterin) which influences cell-cell interactions in vitro. Biol Reprod. 1983;28:1173-88.

11. Kirszbaum L, Sharpe JA, Murphy B, d'Apice AJ, Classon B, Hudson $\mathrm{P}$, Walker ID. Molecular cloning and characterization of the novel, human complement-associated protein, SP-40,40: a link between the complement and reproductive systems. EMBOJ. 1989;8:711-8.

12. Parczyk K, Pilarsky C, Rachel U, Koch-Brandt C. Gp80 (clusterin; TRPM-2) mRNA level is enhanced in human renal clear cell carcinomas. J Cancer Res Clin Oncol. 1994;120:186-8.

13. Hough CD, Cho KR, Zonderman AB, Schwartz DR, Morin PJ. Coordinately up-regulated genes in ovarian cancer. Cancer Res. 2001;61:3869-76.

14. Ouyang XS, Wang X, Lee DT, Tsao SW, Wong YC. Up-regulation of TRPM-2, MMP-7 and ID-1 during sex hormone-induced prostate carcinogenesis in the Noble rat. Carcinogenesis. 2001;22:965-73.

15. Redondo M, Villar E, Torres-Muñoz J, Tellez T, Morell M, Petito CK. Overexpression of clusterin in human breast carcinoma. Am J Pathol. 2000;157:393-9.

16. Chi KN, Eisenhauer E, Fazli L, Jones EC, Goldenberg SL, Powers J, Tu D, Gleave ME. A phase I pharmacokinetic and pharmacodynamic study of OGX-011, a 2'-methoxyethyl antisense 
oligonucleotide to clusterin, in patients with localized prostate cancer. J Natl Cancer Inst. 2005;97:1287-96.

17. Djeu JY, Wei S. Clusterin and chemoresistance. Adv Cancer Res. 2009;105:77-92.

18. Bettuzzi S. Chapter 1: Introduction. Adv Cancer Res. 2009;104:1-8.

19. Chen X, Halberg RB, Ehrhardt WM, Torrealba J, Dove WF. Clusterin as a biomarker in murine and human intestinal neoplasia. Proc Natl Acad Sci U S A. 2003;100:9530-5.

20. Redondo M, Villar E, Torres-Muñoz J, Tellez T, Morell M, Petito CK. Overexpression of clusterin in human breast carcinoma. Am J Pathol. 2000;157:393-9

21. Xie D, Lau SH, Sham JS, Wu QL, Fang Y, Liang LZ, Che LH, Zeng YX, Guan XY. Up-regulated expression of cytoplasmic clusterin in human ovarian carcinoma. Cancer. 2005;103:277-83.

22. Lau SH, Sham JS, Xie D, Tzang CH, Tang D, Ma N, Hu L, Wang Y, Wen JM, Xiao G, Zhang WM, Lau GK, Yang M, Guan XY. Clusterin plays an important role in hepatocellular carcinoma metastasis. Oncogene. 2006;25:1242-50..

23. Saffer H, Wahed A, Rassidakis GZ, Medeiros LJ. Clusterin expression in malignant lymphomas: a survey of 266 cases. Mod Pathol. 2002;15:1221-6..

24. So A, Sinnemann S, Huntsman D, Fazli L, Gleave M. Knockdown of the cytoprotective chaperone, clusterin, chemosensitizes human breast cancer cells both in vitro and in vivo. Mol Cancer Ther. 2005;4:1837-49.

25. Miyake H, Nelson C, Rennie PS, Gleave ME. Acquisition of chemoresistant phenotype by overexpression of the antiapoptotic gene testosterone-repressed prostate message- 2 in prostate cancer xenograft models. Cancer Res. 2000;60:2547-54.

26. Cervellera M, Raschella G, Santilli G, Tanno B, Ventura A, Mancini C, Sevignani C, Calabretta B, Sala A. Direct transactivation of the anti-apoptotic gene apolipoprotein $\mathrm{J}$ (clusterin) by B-MYB. J Biol Chem. 2000;275:21055-60.

27. Chung J, Kwak C, Jin RJ, Lee CH, Lee KH, Lee SE. Enhanced chemosensitivity of bladder cancer cells to cisplatin by suppression of clusterin in vitro. Cancer Lett. 2004;203:155-61.

28. Zellweger T, Miyake H, July LV, Akbari M, Kiyama S, Gleave ME. Chemosensitization of human renal cell cancer using antisense oligonucleotides targeting the antiapoptotic gene clusterin. Neoplasia. 2001;3:360-7.

29. Ahn HJ, Bae J, Lee S, Ko JE, Yoon S, Kim SJ, Sakuragi N. Differential expression of clusterin according to histological type of endometrial carcinoma. Gynecol Oncol. 2008;110:222-9.

30. Ranney MK, Ahmed IS, Potts KR, Craven RJ. Multiple pathways regulating the anti-apoptotic protein clusterin in breast cancer. Biochim Biophys Acta. 2007;1772:1103-11.

31. Flanagan L, Whyte L, Chatterjee N, Tenniswood M. Effects of clusterin over-expression on metastatic progression and therapy in breast cancer. BMC Cancer. 2010;10:107.

32. Leskov KS, Klokov DY, Li J, Kinsella TJ, Boothman DA. Synthesis and functional analysis of nuclear clusterin:a cell death protein. J Biol Chem 2003;278:11590 - 600.

33. Rizzi F, Bettuzzi S. The clusterin paradigm in prostate and breast carcinogenesis. Endocr Relat Cancer. 2010; 17:R1-17.

34. Kim JJ, Chapman-Davis E. Role of progesterone in endometrial cancer. Semin Reprod Med. 2010; 28:81-90.

35. Lange CA, Yee D. Progesterone and breast cancer. Womens Health (Lond Engl). 2008;4:151-62. 